\title{
Current Strategies in Diagnosis of Inherited Storage Pool Defects
}

\author{
Kirstin Sandrock Barbara Zieger \\ Department of Pediatrics and Adolescent Medicine, University Medical Center Freiburg, Germany
}

\author{
Keywords \\ Storage pool disease, SPD - Platelet granules . \\ Platelet dysfunction
}

\section{Summary}

Inherited platelet defects lead to bleeding symptoms of varying severity. Typically, easy bruising, petechiae, epistaxis, and mucocutaneous bleeding are observed in affected patients. The platelet defects are classified into disorders affecting either platelet surface receptors or intracellular organelles of platelets. The latter are represented by platelet storage pool diseases (SPD) which share a defect of platelet granules. Platelet $\alpha$-granules, $\delta$-granules, or both may be affected resulting in the clinical picture of $\alpha$-SPD (e.g. Gray platelet syndrome, Quebec platelet disorder, arthrogryposis, renal dysfunction, and cholestasis syndrome), $\delta$-SPD (e.g. Hermansky-Pudlak syndrome, Chediak-Higashi syndrome, Griscelli syndrome), or $\alpha \delta$-SPD (e.g. X-linked thrombocytopenia, Wiskott-Aldrich syndrome). Diagnosis of SPD is very extensive and requires platelet aggregation and flow cytometry analyses with interpretation from a specialist. Many of these disorders share common treatments, however, efficacy can vary between different patients. Therapy regiments with tranexamic acid, DDAVP, activated FVIIa, and platelet transfusions have been published. Stem cell or bone marrow transplantations are preserved for severe defects. Here, we describe the pathophysiology, clinical manifestations, and diagnosis of the major human SPDs.

\section{Schlüsselwörter \\ Storage-Pool-Defekt, SPD - Thombozytengranula . Thrombozytendysfunktion}

\section{Zusammenfassung}

Angeborene Thrombozytopathien führen zu Blutungssymptomen unterschiedlichen Schweregrades. Typischerweise werden bei den betroffenen Patienten Hämatomneigung, Petechien, Nasenbluten sowie Schleimhautblutungen beobachtet. Die Thrombozytopathien werden durch Störungen der Thrombozytenrezeptoren oder der thrombozytären intrazellulären Organellen verursacht. Letztere werden durch die Storage-Pool-Defekte (SPD) repräsentiert, die einen Defekt der thrombozytären Granula aufweisen. Es können $\alpha$-Granula, $\delta$-Granula oder beide betroffen sein, die jeweils das klinische Bild der $\alpha$-SPD (z.B. Gray-Platelet-Syndrom, Quebec-PlateletDefekt, Arthrogrypose, renale Dysfunktion und Cholestasen), $\delta$-SPD (z.B. Hermansky-Pudlak-Syndrom, ChediakHigashi-Syndrom, Griscelli-Syndrom) oder $\alpha \delta$-SPD (z.B. X-chromosomale Thrombozytopenie, Wiskott-AldrichSyndrom) aufweisen. Die Diagnostik von SPD ist sehr aufwendig und benötigt eine Untersuchung der Thrombozytenaggregation sowie durchflusszytometrische Analysen, die von einem Spezialisten interpretiert werden sollten. Die Therapien mit Tranexamsäure, DDAVP, aktiviertem Faktor FVIla oder Thrombozytentransfusionen sprechen bei Patienten mit Thrombozytopathien nicht gleich gut an. Stammzell- oder Knochenmarkstransplantationen sind schweren Formen vorbehalten. In diesem Review werden Pathophysiologie, klinische Manifestation und Diagnostik der wichtigsten SPDs zusammengefasst.

\section{KARGER}

Fax +497614520714

Information@Karger.de

www.karger.com (c) 2010 S. Karger GmbH, Freiburg

Accessible online at:

www.karger.com/tmh 


\section{Introduction}

Inherited defects of platelet function are classified according to their effect on the various steps of platelet function and involve membrane receptor defects and storage pool deficiencies. Severe forms of platelet dysfunction are associated with deficiencies in platelet membrane receptors, but defects in the number and distribution of secretory granules can also cause significant bleeding. Storage pool disease (SPD) is a heterogeneous group of congenital disorders that have a deficiency of granules or their constituents in common. Absence of platelet granules results in a defective secretion (e.g. ADP) from activated platelets as well as abnormal secretion-dependent platelet aggregation [1]. In some disorders, such as ChediakHigashi (CHS), Hermansky-Pudlak (HPS), or WiskottAldrich (WAS) syndromes, the molecular lesion extends to other cells.

Platelet granules are classified into $\alpha$-granules and $\delta$-granules (dense bodies). The $\alpha$-granules are storage sites for proteins that are either synthesized in megakaryocytes (MKs) or endocytosed from plasma [2]. $\alpha$-granules contain numerous proteins involved in platelet adhesion (von Willebrand factor (VWF), P-selectin, fibronectin, fibrinogen), coagulation factors (factors $\mathrm{V}$ and XIII), growth factors (platelet-derived growth factor, transforming growth factor- $\beta$ ), and platelet factor-4. The $\delta$-granules contain primarily calcium, ATP, ADP, serotonin, histamine, and epinephrine.

According to the storage pool-deficient platelets, which have decreased amounts of $\alpha$-granules, $\delta$-granules, or both, and their specific constituents, the clinical syndrome is called $\alpha$-SPD, $\delta$-SPD, or combined $\alpha \delta$-SPD. These disorders, affecting the extension phase of clot formation, are associated with impaired platelet function as indicated by decreased aggregation responses. This review gives an overview about the known clinical phenotypes of SPDs associated with the absence of $\alpha$ - and/or $\delta$-granules (table 1 ). Careful clinical and molecular diagnosis is essential to differentiate the complex disorders of lysosomal trafficking.

\section{$\alpha$-Storage Pool Disease}

\section{Gray Platelet Syndrome}

\section{Introduction}

Gray platelet syndrome (GPS) was first described by Raccuglia in 1971 as a qualitative defect in platelets [3]. The rare inherited disorder presents with bleeding tendency, moderate thrombocytopenia associated with a marked decrease, or absence of platelet $\alpha$-granules and their contents. Hallmark of the disease is the failure of MK proteins to enter into the secretable storage pools that characterize $\alpha$-granules of normal platelets. GPS platelets specifically lack $\alpha$-granules probably due to their failed maturation during MK differentiation
[4]. Numbers of mitochondria, dense bodies, peroxisomes, and lysosomes are normal.

Case reports suggesting autosomal dominant [5] as well as autosomal recessive [6] inheritance have been described, indicating that GPS is probably a genetically heterogeneous disorder. The molecular defect(s) responsible for GPS remain(s) to be determined.

\section{Pathophysiology}

MKs show defective $\alpha$-granule production, with impaired uptake and storage of endogenously synthesized proteins, such as platelet factor-4, $\beta$-thromboglobulin, VWF, or multimerin (a multimeric factor V-binding protein), and defective storage of exogenous proteins, such as fibrinogen, albumin, or factor $\mathrm{V}$.

\section{Clinical Manifestations}

GPS patients present with mild to moderate bleeding symptoms such as easy bruising, petechiae, and epistaxis. Mucosal membrane bleeding may also occur. Bleeding time is prolonged. While platelets of some patients aggregate normally, for other patients thrombin- and/or collagen-induced platelet aggregation is impaired. A feature of most patients is the early onset of myelofibrosis, a disorder attributed to the spontaneous release of newly synthesized growth factors from MKs [7]. Jantunen et al. [8] reported on a GPS patient with myelofibrosis and splenomegaly indicating extramedullary hematopoiesis. Splenectomy has produced a temporary or even longstanding rise in platelet counts, however, without significant effect on bleeding tendency. The patient has been followed for more than 15 years without apparent progression of myelofibrosis.

Granule abnormalities in granulocytes have been reported in one family, indicating that the defect may not be restricted to platelets [9]. Nurden et al. [6] report a novel case of GPS where a severe deficiency of the platelet collagen receptor, glycoprotein (GP) VI, accompanies classical GPS symptoms such as bleeding diathesis and enlarged gray platelets. However, no mutations were identified in the GPVI gene. In addition, decreased levels of platelet membrane TLT1 (TREMlike transcript-1), which is located in the $\alpha$-granule membrane, and decreased levels of P-selectin were found in this patient [10]. The authors postulate that excess activity of metalloproteases may have caused the decrease of these proteins. Taken together, GPS patients exhibit much heterogeneity concerning biochemical, phenotypic, and molecular characteristics.

\section{Diagnosis}

Blood smear typically reveals mild to moderate thrombocytopenia and enlarged (but not giant) platelets that have a gray appearance. Platelet aggregation studies are variable with no classical response pattern to ADP, epinephrine, thrombin, or collagen [7]. 
Table 1. Inherited storage pool diseases (SPD): genetic mutations and associated phenotypes

\begin{tabular}{|c|c|c|c|c|c|c|}
\hline Syndrome & $\begin{array}{l}\text { Bleeding } \\
\text { symptoms }\end{array}$ & $\begin{array}{l}\text { Platelet count } \\
\times 10^{9} / 1\end{array}$ & $\begin{array}{l}\text { Platelet } \\
\text { ultrastructure }\end{array}$ & $\begin{array}{l}\text { Inheritance } \\
\text { (gene) }\end{array}$ & $\begin{array}{l}\text { Platelet function } \\
\text { abnormality }\end{array}$ & Associations \\
\hline \multicolumn{7}{|c|}{$\alpha$-Storage pool disease $(\alpha-S P D)$} \\
\hline GPS & $\begin{array}{l}\text { mild to } \\
\text { moderate }\end{array}$ & $30-100$ & $\begin{array}{l}\downarrow / \text { empty } \\
\alpha \text {-granules, } \\
\uparrow \text { platelet size }\end{array}$ & $\begin{array}{l}\text { autosomal recessive } \\
\text { (most) or dominant } \\
\text { (gene(s) unknown) }\end{array}$ & $\begin{array}{l}\text { normal or } \downarrow \\
\text { aggregation with } \\
\text { thrombin, collagen }\end{array}$ & myelofibrosis \\
\hline QPD & $\begin{array}{l}\text { mild to } \\
\text { moderate }\end{array}$ & normal or $\downarrow$ & $\begin{array}{l}\downarrow \alpha \text {-granule } \\
\text { content }\end{array}$ & $\begin{array}{l}\text { autosomal dominant } \\
(P L A U)\end{array}$ & $\begin{array}{l}\downarrow \text { aggregation with } \\
\text { epinephrine }\end{array}$ & \\
\hline ARC syndrome & mild & normal & $\begin{array}{l}\text { lack of } \alpha \text {-granules, } \\
\uparrow \text { platelet size }\end{array}$ & $\begin{array}{l}\text { autosomal recessive } \\
(V P S 33 B, V I P A R)\end{array}$ & $\begin{array}{l}\downarrow \text { aggregation with } \\
\text { ADP, arachidonate }\end{array}$ & $\begin{array}{l}\text { arthrogryposis multiplex } \\
\text { congenita, renal } \\
\text { dysfunction, cholestasis, } \\
\text { ichthyosis, } \\
\text { recurrent infections }\end{array}$ \\
\hline \multicolumn{7}{|c|}{$\delta$-Storage pool disease $(\delta-S P D)$} \\
\hline HPS (subtype 1-8) & $\begin{array}{l}\text { moderate } \\
\text { to severe }\end{array}$ & normal & $\downarrow$ dense granules & $\begin{array}{l}\text { autosomal recessive } \\
\text { (HPS1-HPS } 8)\end{array}$ & $\begin{array}{l}\downarrow \text { second wave of } \\
\text { aggregation }\end{array}$ & $\begin{array}{l}\text { oculocutaneous albinism, } \\
\text { ceroidlipo-fuscinosis, } \\
\text { nystagmus, } \\
\downarrow \text { visual acuity, (HPS2: } \\
\text { immunodeficiency, HLH; } \\
\text { HPS1,4: granulomatous } \\
\text { colitis, pulmonary fibrosis) }\end{array}$ \\
\hline CHS & $\begin{array}{l}\text { moderate } \\
\text { to severe }\end{array}$ & normal & $\begin{array}{l}\downarrow \text { dense granules, } \\
\text { giant inclusion } \\
\text { bodies }\end{array}$ & $\begin{array}{l}\text { autosomal recessive } \\
(L Y S T)\end{array}$ & $\begin{array}{l}\downarrow \text { second wave of } \\
\text { aggregation, } \\
\uparrow \text { ATP/ADP ratio }\end{array}$ & $\begin{array}{l}\text { partial albinism, } \\
\text { immunodeficiency, HLH, } \\
\text { neurological defects, } \\
\text { hepatosplenomegaly }\end{array}$ \\
\hline GS (subtype 1-3) & $\begin{array}{l}\text { mild } \\
\text { to absent }\end{array}$ & normal or $\downarrow$ & n.d. & $\begin{array}{l}\text { autosomal recessive } \\
(M Y O 5 A, R A B 27 A, \\
M L P H)\end{array}$ & n.d. & $\begin{array}{l}\text { partial albinism, silver hair, } \\
\text { (GS1: neurological defects; } \\
\text { GS2: immunodeficiency) }\end{array}$ \\
\hline \multicolumn{7}{|c|}{$\alpha \delta$-Storage pool disease $(\alpha \delta$-SPD) } \\
\hline $\begin{array}{l}\text { X-linked } \\
\text { dyserythropoietic } \\
\text { anemia with } \\
\text { thrombocytopenia/ } \\
\text { X-linked } \\
\text { macrothrombo- } \\
\text { cytopenia }\end{array}$ & moderate & mostly $\downarrow$ & $\begin{array}{l}\downarrow \text { dense granules, } \\
\text { variable } \alpha \text {-granules, } \\
\uparrow \text { platelet size }\end{array}$ & $\begin{array}{l}\text { X-linked dominant, } \\
(G A T A 1)\end{array}$ & $\downarrow$ aggregation & $\begin{array}{l}\beta \text {-thalassemia, congenital } \\
\text { erythropoietic porphyria }\end{array}$ \\
\hline WAS & $\begin{array}{l}\text { moderate } \\
\text { to severe }\end{array}$ & $10-100$ & $\begin{array}{l}\downarrow \text { granules, } \\
\downarrow \text { platelet size }\end{array}$ & $\begin{array}{l}\mathrm{X} \text {-linked recessive } \\
(W A S)\end{array}$ & $\downarrow$ aggregation & $\begin{array}{l}\text { eczema, immunodeficiency, } \\
\text { risk for autoimmune } \\
\text { disorders }\end{array}$ \\
\hline
\end{tabular}

n.d. $=$ Not detected

\section{Quebec Platelet Disorder}

\section{Introduction}

Quebec platelet disorder (QPD) is a rare, autosomal dominant bleeding disorder described in two families from the province of Quebec in Canada [11, 12]. The disorder is characterized by mild thrombocytopenia, moderately reduced platelet factor $\mathrm{V}$ clotting activities, and bleeding risk. In addition, QPD $\alpha$-granule proteins are decreased in amount probably due to significant degradation [13]. Interestingly, protein degradation is restricted to $\alpha$-granules, but does not occur in blood plasma.

\section{Pathophysiology}

$\alpha$-Granule protein levels such as factor $\mathrm{V}$, fibrinogen, VWF, thrombospondin, fibronectin, $\mathrm{P}$-selectin, and osteonectin are significantly degraded in QPD platelets [13]. In contrast, platelet factor-4 and $\beta$-thromboglobulin do not appear to be affected. QPD platelets also showed quantitative deficiency in the $\alpha$-granule protein multimerin with a normal multimer pattern [14].

Unlike normal platelets, QPD platelets contain increased amounts of the fibrinolytic serine protease urokinase-type plasminogen activator (u-PA, PLAU) without increased plasma u-PA or systemic fibrinolysis [15]. During clot formation, u-PA released by QPD platelets leads to increased plate- 
Fig. 1. Post-Golgi sorting in conventional cell types and melanocytes: The role of HPS proteins as well as VPS33B in vesicle trafficking is demonstrated. These proteins affect the synthesis of lysosomes and LROs in the endocytic pathway. The different BLOC protein complexes cause the accumulation of melanosomes in different stages during melanosome biogenesis. Other proteins (e.g. Rab27a) can affect lysosome maturation at other subcellular sites (interaction with the cytoskeleton). ER = Endoplasmatic reticulum, TGN = trans-Golgi network, BLOC = biogenesis of lysosomerelated organelle complex. Adapted from Li et al. [34].

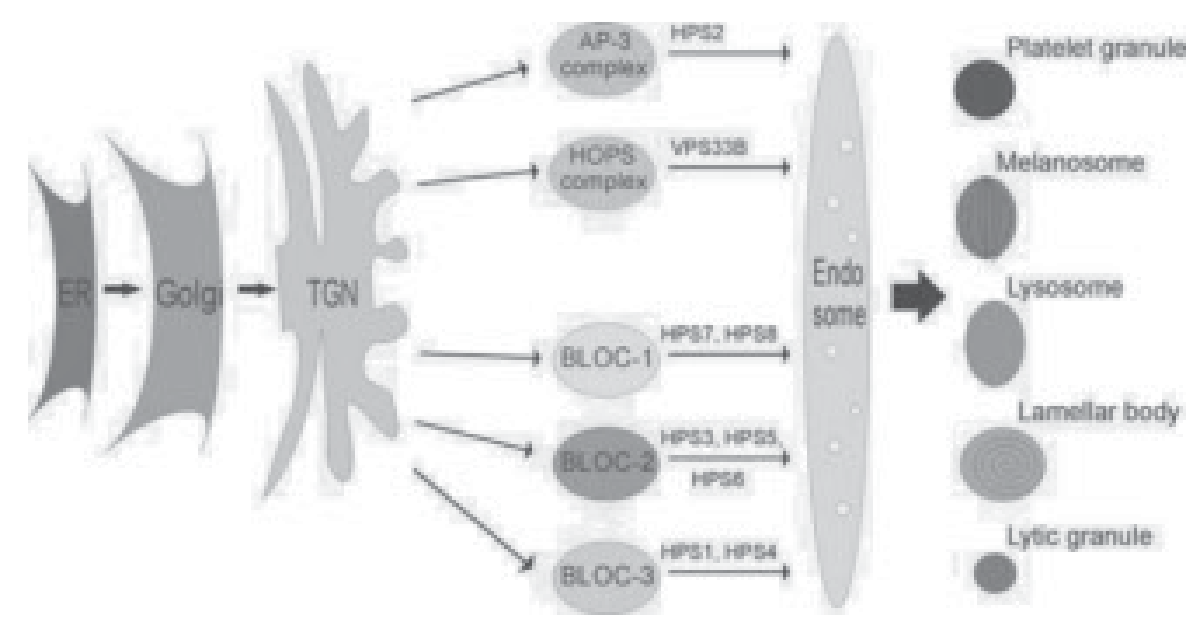

let-dependent fibrinolysis. These data implicate u-PA in the pathogenesis of $\alpha$-granule protein degradation and bleeding diathesis in QPD. Remarkably increased transcript levels of u-PA mRNA during MK differentiation were linked to a mutation in an uncharacterized regulatory element near the PLAU allele as cause of QPD [16]. Recently, QPD patients were identified to have a direct tandem duplication of a 78-kb genomic segment including $P L A U$ and all of its characterized regulatory elements [17]. It is possible that the QPD duplication mutation further increases PLAU expression during megakaryopoiesis by other mechanisms such as alternative transcription, splicing, and/or histone binding.

\section{Clinical Manifestations}

Typically, QPD manifests as delayed-onset bleeding following hemostatic challenges (12-24 h after traumata) that responds to fibrinolytic inhibitor therapy, with or without increased bruising, episodic joint bleeds, and spontaneous hematuria [18]. Other symptoms may include excessive bleeding after cuts and delayed wound healing. QPD life expectancy appears to be similar to other family members since fatal bleeding episodes are rare.

\section{Diagnosis}

QPD platelets show protease-related degradation of many $\alpha$-granule proteins even though $\alpha$-granule ultrastructure is preserved. Thrombocytopenia is sometimes observed. QPD platelets fail to aggregate in response to epinephrine with or without reduced aggregation with ADP and collagen.

\section{Arthrogryposis, Renal Dysfunction, and Cholestasis Syndrome}

\section{Introduction}

ARC (arthrogryposis, renal dysfunction, and cholestasis) syndrome is a severe autosomal recessive multisystem disorder associated with arthrogryposis multiplex congenita and abnor- malities in polarized liver and kidney cells. This association was first reported in 1973 by Lutz-Richner and Landolt and again in another family by Nezelof et al. in 1979 [19]. ARC syndrome leads to death in infancy (by the age of about 6 months). Those patients surviving longer have shown severe developmental delay [20]. Soluble as well as membranebound $\alpha$-granule proteins were significantly decreased or undetectable, i.e. both the releasable protein pools and membrane components of $\alpha$-granules were absent.

\section{Pathophysiology}

By elucidating the molecular basis of ARC, germline mutations in the VPS33B gene were identified [21]. VPS33B (vacuolar protein sorting 33 homolog B) demonstrates a homolog of the class $\mathrm{C}$ yeast vacuolar protein sorting protein (Vps33) that contains a Sec1-like domain and belongs to the family of SM (Sec1/Munc18-like) proteins. SM proteins are important in the regulation of SNARE(soluble N-ethylmaleimide-sensitive factor attachment receptor)-dependent complex formation and subsequent membrane fusion. VPS33B may be involved in intracellular vesicle trafficking, being essential for the development of platelet $\alpha$-granules but not for granule secretion (fig. 1) [22]. Because some ARC patients showed no mutation in the VPS33B gene, the evidence for a possible second ARC locus was postulated [23]. Recently, Cullinane et al. [24] identified mutations in VIPAR (VPS33B-interacting protein involved in polarity and apical protein restriction) in ARC patients without VPS33B defects. VPS33B and VIPAR may function as part of a complex that is involved in apical membrane protein sorting.

\section{Clinical Manifestations}

Patients with ARC syndrome present with arthrogryposis, renal tubular dysfunction (Fanconi syndrome), and cholestasis with a low $\gamma$ GT ( $\gamma$-glutamyltransferase) activity. However, cases may stay undiagnosed as not all patients present with the three cardinal features. Typically, patients present with recurrent fever, infections (e.g. pneumonia), and failure to 
thrive. Further clinical symptoms such as ichthyosis, central nervous system (CNS) defects, neurogenic muscular atrophy, nephrogenic diabetes insipidus, anemia, and diarrhea have been reported [25]. Case reports showed that ARC patients may have a bleeding tendency. It has become apparent that there is notable clinical variability, even within the same family. No clear genotype-phenotype correlations were identified.

\section{Diagnosis}

Blood smear revealed abnormally large platelets with pale appearance, absent $\alpha$-granules, and increased number of $\delta$-granules. Low concentrations of $\beta$-thromboglobulin, platelet factor-4, and thrombospondin can be measured [26]. ARC platelets demonstrate reduced aggregation with arachidonic acid and ADP [22]. Diagnosing ARC syndrome by liver biopsy is associated with a substantial risk of morbidity and mortality. However, none of the patients with abnormal platelet function had episodes of spontaneous bleeding, but patients may suffer from severe hemorrhage after organ biopsy [23]. Thus, direct sequencing of VPS33B and VIPAR is an alternative method to provide molecular diagnosis in ARC patients.

\section{$\delta$-Storage Pool Disease}

$\delta$-Storage pool deficiency $(\delta$-SPD) can develop isolated or in combination with complex disorders such as HPS, CHS, WAS, or thrombocytopenia-absent radius (TAR) syndrome.

Typically, $\delta$-SPD is associated with reduced adenine nucleotide (AN) and serotonin levels while ABCC4 (ATP-binding cassette, sub-family $\mathrm{C}$, member 4 protein) is quantitatively normal. However, recently, patients with a $\delta$-SPD-like phenotype were described demonstrating absence of ABCC4 as well as reduced AN but normal serotonin levels. The authors postulate that impaired expression of $\mathrm{ABCC} 4$ mediates the defect in AN storage [27]. However, the genetic basis of the new $\delta$-SPD phenotype remains to be determined.

\section{Hermansky-Pudlak Syndrome}

\section{Introduction}

HPS, a rare autosomal recessive disorder, was first described by the Czechoslovakian physicians Hermansky and Pudlak in 1959 [28]. They reported on two unrelated patients with oculocutaneous albinism, congenital nystagmus, lifelong bleeding tendency, and unusual pigmented macrophages in bone marrow and lymph nodes. In addition, one patient had interstitial pulmonary fibrosis and died at the age of 34 years.

Since then, HPS has been recognized as a group of genetically distinct diseases resulting from abnormal formation or trafficking of intracellular vesicles. The specific organelles affected in HPS are the lysosomes and lysosome-related organelles (LROs), such as the melanosomes and the platelet dense bodies, which all share certain integral membrane proteins $[29,30]$. Impairment of melanosome formation results in oculocutaneous albinism [31] and absence of platelet dense bodies causes a bleeding diathesis. Most probably, due to mistrafficking of a subset of lysosomes, some HPS patients accumulate ceroid lipofuscin, an amorphous lipid-protein complex thought to be stored within cellular lysosomes, leading to granulomatous colitis or severe pulmonary fibrosis.

Patients of nearly all ethnic groups have been diagnosed with HPS. However, this disorder is frequent in Puerto Rico and in an isolated mountain village high in the Swiss Alps $[32,33]$.

\section{Pathophysiology}

While at least 15 distinct genes were cloned in the mouse, in humans 8 genes (HPS1-HPS8) have been found causing hypopigmentation and platelet storage pool deficiency. It is likely that additional human HPS genes will be discovered, corresponding to the known mouse strains. All HPS proteins are associated in multi-protein complexes essential for biogenesis and intracellular trafficking of LROs [34] (fig. 1). The defined function of the particular subunits of these multi-protein complexes is not yet determined. The BLOC-1 (biogenesis of lysosome-related organelle complex-1) includes as subunits HPS7 (Dysbindin), HPS8 (BLOS3), and the mouse gene products of pallidin, muted, cappuccino, snapin, BLOS1 and BLOS2. BLOC-2 contains HPS3, HPS5, and HPS6. BLOC-3 involves HPS1 and HPS4 as subunits. The adapter protein complex AP-3 comprises the HPS2 ( $\beta 3 \mathrm{~A})-, \delta-, \mu 3$ - and $\sigma 3$-subunits. Mutations within particular HPS genes can lead to dysfunction of the corresponding protein complex and thus to defective maturation of melanosomes and platelet dense bodies. The human HPS subtypes (HPS1-HPS8) have in part different clinical features. Patients with those defects of HPS proteins that belong to the same multi-protein complex (e.g. BLOC-3) show a similar clinical HPS phenotype (HPS1, HPS4) (table 2).

\section{Clinical Manifestations}

All HPS phenotypes present with oculocutaneous albinism, decreased visual acuity, congenital nystagmus, and mild to severe bleeding symptoms including easy bruising, epistaxis, petechiae, and prolonged bleeding after surgery or trauma. Skin diseases can include solar keratoses, squamous cell and basal cell carcinoma. HPS1 and HPS4 patients may additionally show restrictive lung disease (78\% of HPS1 patients / 14\% of HPS4 patients) or granulomatous colitis (15\%/43\%) [35].

Neutropenia and susceptibility to recurrent infections, primarily respiratory illness, have been exclusively observed in HPS2 patients so far. In addition, hip dislocations secondary to dysplastic acetabulae, neurological abnormalities including poor balance, and conductive hearing loss can occur in HPS2 
Table 2. Hermansky-Pudlak syndrome (HPS) subtypes and clinical phenotypes ${ }^{\mathrm{a}}$

\begin{tabular}{|c|c|c|c|}
\hline HPS subtype & Protein complex & Clinical features & \\
\hline $\begin{array}{l}\text { HPS1 (pale ear) } \\
\text { HPS4 (light ear) }\end{array}$ & BLOC-3 & $\begin{array}{l}\text { restrictive lung disease } \\
\text { granulomatous colitis }\end{array}$ & \\
\hline HPS2 (AP3B1; pearl) & AP-3 & $\begin{array}{l}\text { immunodeficiency } \\
\text { neutropenia } \\
\text { recurrent infections } \\
\text { dysplastic acetabulae } \\
\text { poor balance } \\
\text { conductive hearing loss }\end{array}$ & \\
\hline $\begin{array}{l}\text { HPS3 (cocoa) } \\
\text { HPS5 (ruby eye-2) } \\
\text { HPS6 (ruby eye) }\end{array}$ & BLOC-2 & $\begin{array}{l}\uparrow \text { creatinine clearance } \\
\text { hypercholesterolemia (HPS5) } \\
\text { respiratory and urinary tract infections (HPS6) } \\
\text { urinary and rectal incontinence (HPS6) } \\
\text { hearing loss (HPS6) } \\
\text { global developmental delay (HPS6) }\end{array}$ & $\begin{array}{l}\text { variable pigment dilution } \\
\text { decreased visual acuity } \\
\text { nystagmus } \\
\text { variable bleeding symptoms }\end{array}$ \\
\hline $\begin{array}{l}\text { HPS7 (dysbindin; sandy) } \\
\text { HPS8 (BLOS3; reduced pigmentation) } \\
\text { Pallidin } \\
\text { Muted } \\
\text { Cappuccino } \\
\text { Snapin } \\
\text { BLOS1 } \\
\text { BLOS2 }\end{array}$ & BLOC-1 & $\begin{array}{l}\text { mild shortness of breath on exertion (HPS7) } \\
\text { reduced lung compliance (HPS7) }\end{array}$ & \\
\hline
\end{tabular}

${ }^{a}$ Human and mouse (italic) HPS gene mutations as cause of the clinical HPS phenotype. All HPS proteins are part of several multi-protein complexes.

patients. So far, one patient with HPS2 who developed fulminant hemophagocytic lymphohistiocytosis (HLH) has been described [36].

HPS3 is clinically mild compared with HPS1. Interestingly, most HPS5 patients demonstrate elevated cholesterol and triglyceride levels as well as increased creatinine clearance. The first three HPS6 patients did not show severe phenotypes. However, a recent study reports on a 36-year-old female patient with a history of multiple abdominal surgeries requiring several red blood cell and platelet transfusions, four miscarriages, endometriosis, heavy menses, urinary and rectal incontinence with neurogenic bladder dysfunction, frequent migraines, and hearing loss [37]. A 13-year-old patient presented with global developmental delay with a handicap in both motor function and speech/language. A 52-year-old man has a history of esophageal dysmotility, hiatal hernia, and other gastrointestinal complications including gastro-esophageal reflux disease and dysphagia [37].

The only known HPS7 patient, a 48-year-old Portuguese woman, showed mild shortness of breath on exertion and reduced lung compliance. However, pulmonary function and computed tomography (CT) chest scans were normal [38]. Interestingly, DTNBP1 (dystrobrevin-binding protein 1, HPS7) gene variants were shown to be associated with schizophrenia; however, this correlation is controversial [39, 40]. A Pakistani family with several HPS8 patients, all carrying the same mutation, did not demonstrate further clinical complications except the common clinical HPS phenotype (bleeding symptoms, oculocutaneous albinism, decreased visual acuity) [41].

\section{Diagnosis}

Striking clinical symptoms in HPS patients are the tyrosinasepositive oculocutaneous albinism, nystagmus, decreased visual acuity, and a bleeding diathesis (fig. 2A). Bleeding time is prolonged. Electron microscopy and peripheral blood smear should reveal normal platelet count with absent or few platelet dense bodies. Platelet agglutination/aggregation after stimulation with ristocetin, ADP, collagen, epinephrine, and arachidonic acid typically shows a significantly impaired second wave. HPS patients' platelets demonstrate the absence of platelet $\delta$-granule secretion whereas $\alpha$-granule secretion is normal (fig. 2B). Molecular genetic analysis allows the confirmation of the diagnosis as well as the classification into a particular HPS subtype (HPS1-8) which is important for therapy and prognosis.

\section{Chediak-Higashi Syndrome}

\section{Introduction}

Sato (1955) reported 'Chediak and Higashi's disease', the probable identity of a new leukocyte anomaly (Chediak) and congenital gigantism of peroxidase granules (Higashi) [42]. Donohue and Bain, using the specific designation CHS, de- 
Fig. 2. Clinical phenotype of a HPS patient. A Photo of a HPS1 patient demonstrating oculocutaneous albinism. B Expression of CD63 agonist on patient's platelets showing impaired $\delta$-granule secretion was detected by flow cytometry.

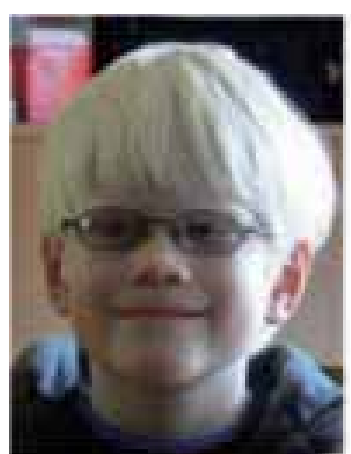

A

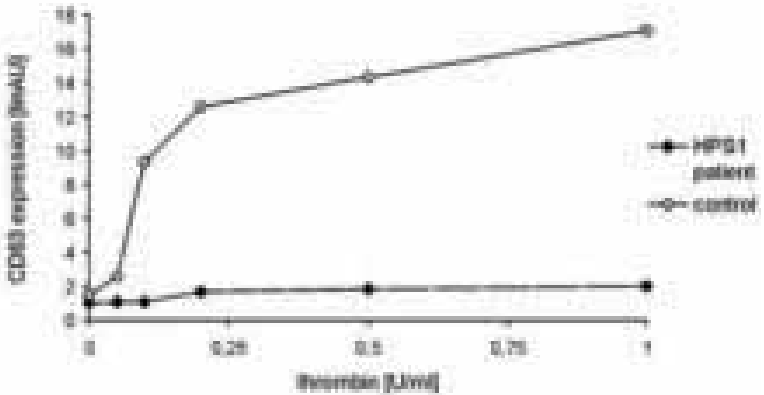

日 scribed a lethal familial disease with anomalous inclusions in the leukocytes and constitutional stigmata [43]. In CHS, a rare autosomal recessive disease, the bleeding diathesis is associated with severe immunologic defects and progressive neurological dysfunction if the patient survives to adulthood.

\section{Pathophysiology}

The CHS gene (LYST; lysosomal trafficking regulator) was identified as responsible for CHS [44, 45]. The LYST protein regulates LRO size and movement, although its defined role is not known yet. LYST is predicted to be a cytosolic protein that mediates membrane interactions. Multiple LYST frameshift and nonsense mutations were initially described resulting in a truncated CHS protein and a severe phenotype $[46,47]$. Rarely, missense mutations are associated with a milder form of the disease.

\section{Clinical Manifestations}

Like HPS, CHS is also characterized by oculocutaneous albinism and dense granule deficiency leading to platelet disorder and prolonged bleeding tendency. In addition, CHS patients present with severe immunodeficiency leading to life-threatening bacterial infections. The clinical picture of CHS is similar to that of HPS2. In the so-called accelerated phase of CHS, approximately $85 \%$ of CHS patients develop HLH with fever, anemia, neutropenia, thrombocytopenia, hepatosplenomegaly, and lymphadenopathy. If CHS patients survive until adulthood, they develop neurological defects including neuropathies, autonomic dysfunction, atrophy, sensory deficits, cerebellar signs, seizures, and cognitive defects. Only hematopoietic stem cell transplantation (HSCT) has been shown to improve the long-term outcome of this otherwise fatal disease [48]. In contrast to the immunological disorders, the neurological symptoms seem not to be prevented by HSCT.

\section{Diagnosis}

The hallmark of CHS is the presence of giant inclusion bodies in a variety of granule-containing cells (fig. 3). Lysosomes, melanosomes, platelet dense granules, and cytolytic granules are affected. Platelet counts are normal. Interestingly, the sec-
Fig. 3. Blood smear of a CHS patient demonstrating giant inclusion bodies in the cytoplasm of leukocytes.

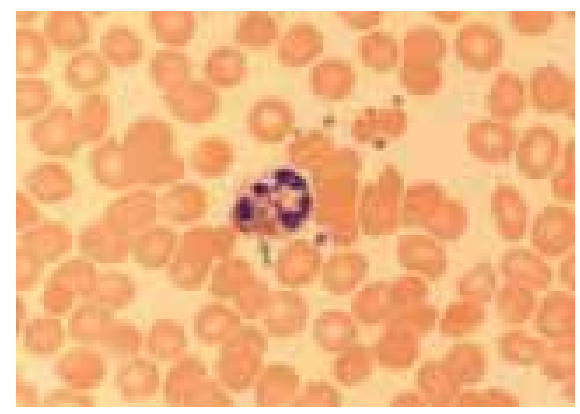

Fig. 4. Large pigmentary clumps in the hair shaft of a GS patient.

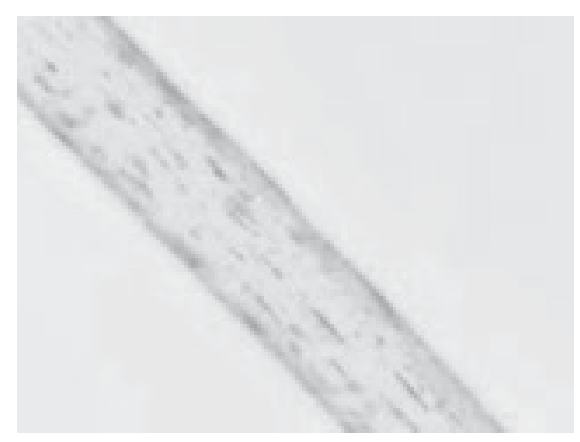

ondary wave of platelet aggregation is impaired and platelets show an increased ATP- to ADP-ratio and a decreased amount of serotonin and calcium. Molecular genetic analysis of the LYST gene allows the confirmation of the diagnosis. The type of the LYST mutation may influence the severity of the disease.

\section{Griscelli Syndrome}

\section{Introduction}

Griscelli syndrome (GS), a rare autosomal recessive disorder, was first described in 1978 [49, 50]. GS is characterized by pigmentary dilution of the skin, a silver-grey shine of the hair, large clumps of pigment within hair shafts (fig. 4), and the accumulation of large and abnormal end-stage melanosomes in the centre of melanocytes. 
Patients with GS can be categorized in 3 types. Type 1 (GS1) manifests with severe primary neurological impairment including developmental delay and mental retardation. Mutations within the MYO5A (myosin Va) gene, which encodes an organelle motor protein, myosin Va (MYO5A), were identified as causing GS1 [51, 52]. Type 2 (GS2) is associated with potentially lethal immunodeficiency and HLH. GS2 is associated with mutations in $R A B 27 A$ which encodes a small GTPase protein (Rab27a) involved in the function of the intracellular-regulated secretory pathway [53]. Type 3 (GS3) only has dermatological manifestations and results from mutations in the gene encoding melanophilin $(M L P H)$ [52].

\section{Pathophysiology}

Inside the melanocytes, mature melanosomes are transported from the cell centre to the cell periphery. This bidirectional transport takes place along microtubule tracks and the sublemmal actin-network. The latter process involves the processive motor protein MYO5A, which attaches to melanosomes through interaction with MLPH and Rab27a [54]. Several molecular studies have already revealed that mutations within any member of the Rab27a-MLPH-MYO5A tripartite complex cause one of the three GS subtypes.

MYO5A functions as a dimeric, actin-based molecular motor protein containing ATP-binding sites as well as actinbinding capability. The ATP-binding sites can convert energy through ATP hydrolysis, generating a mechanical movement along the actin filaments. Rab27a, a member of the Ras super family of small GTPases, is essential for membrane trafficking by targeting, docking, and fusion of transport vesicles with their appropriate acceptor membranes in different mammalian cell types. In addition to its role in melanocytes, the Rab27a protein also functions in granule release within cytotoxic T lymphocytes. Therefore, defective Rab27a in GS2 patients also leads to immunodeficiency. The recently identified MLPH belongs to a novel class of the family of the synaptotagmin-like protein (SLP). MLPH is the specific linker protein between MYO5A and Rab27a.

\section{Clinical Manifestations}

In patients with GS1 (hypotonia, statomotoric, and mental retardation, without a history of infections), MYO5A mutations were identified [55]. Since the second series of Elejalde syndrome patients [56] had clinical and histologic features similar to GS1, it was suggested that in some patients Elejalde syndrome and GS1 represent the same entity [57, 58]. Patients with Elejalde syndrome as well as with GS1 present with mental retardation and profound neurologic dysfunction including severe muscular hypotonia, ocular alterations, and seizures.

As the original patients described by Griscelli manifested partial albinism, frequent pyogenic infections, and acute episodes of fever, neutropenia, and thrombocytopenia, these patients were expected to have GS2 [49]. While most GS2 patients also develop uncontrolled $\mathrm{T}$ lymphocyte and macro- phage activation syndrome, often associated with HLH, leading to death in the absence of HSCT [53], some show severe neurologic impairment early in life without apparent immune abnormalities. Although the ashen mouse which lacks Rab27a presents with platelet storage pool deficiency including prolonged bleeding time [59], reports on prolonged bleeding in GS2 patients were missing.

The neurologic manifestation in GS1 and GS2 seems to have a distinct origin: several reports established that neurologic manifestations in patients with GS caused by $R A B 27 A$ mutations (GS2) were related to lymphocyte infiltration of the CNS [53, 55], whereas patients with GS caused by MYO5A mutations (GS1) exhibited a primary neurologic disease unrelated to the hematopoietic lineage [56].

In one patient with hypopigmentation without any immunologic or neurologic manifestations, a homozygous mutation in the $M L P H$ gene was identified and referred to GS3 [52]. So far, it is unclear why GS3 only presents with hypomelanosis but not with neurologic or immunologic defects.

\section{Diagnosis}

Three types of human GS are recognized, all displaying pigment dilution of the hair and skin. Different subtypes include neurological defects (GS1) or severe immunodeficiency with a defective cytotoxic activity of lymphocytes (GS2). GS patients do not have an obvious bleeding tendency; whether they have a defect in platelet $\delta$-granules is not known. Differential diagnosis of GS2 with HPS2 can be difficult.

\section{$\alpha \delta$-Storage Pool Disease}

In the combined $\alpha$ - and $\delta$-storage pool disease ( $\alpha \delta$-SPD), $\delta$-granules are always decreased, while the number of $\alpha$-granules varies. Patients' platelet population is typically inhomogeneous; some platelets may have significantly more $\alpha$ - and/or $\delta$-granules than others [60].

\section{X-Linked Dyserythropoietic Anemia with Thrombocytopenia/ $X$-Linked Macrothrombocytopenia}

\section{Introduction}

The X-linked dyserythropoietic anemia with thrombocytopenia/ $\mathrm{X}$-linked macrothrombocytopenia is characterized by thrombocytopenia and/or anemia ranging from mild to severe and can include platelet dysfunction, $\beta$-thalassemia, neutropenia, and congenital erythropoietic porphyria. Since the disorder is inherited in an X-linked dominant matter, all male family members carrying the mutated allele are affected. Several inherited mutations in GATA1 are associated with distinct clinical phenotypes such as 'familial dyserythropoietic anemia with thrombocytopenia' [61, 62], 'X-linked macrothrombocytopenia' (with or without anemia), and 'congenital erythropoietic porphyria' [63]. 


\section{Pathophysiology}

Vertebrate erythroid cells contain the tissue-specific transcription factor GATA1 as the founding member of the GATA factor family, which is known to regulate the expression of a large number of genes in multiple cell types. Since GATA1 has been shown to be essential for normal hematopoiesis, especially for erythropoiesis and megakaryopoiesis, mutations within GATA1 cause characteristic hematologic disorders. Both inherited and acquired hematological diseases due to GATA1 mutation have been reported in several families [64]. A low transcription of the GATA-1 target genes, $G P I b \alpha$ and $G P I X$, is a characteristic of GATA-1 pathologies.

\section{Clinical Manifestations}

The clinical picture of X-linked dyserythropoietic anemia with thrombocytopenia/X-linked macrothrombocytopenia varies. Thrombocytopenia was observed in all patients, however, anemia did not occur in all patients $[65,66]$. Typically, in infancy the patients present with easy bruising, mucosal bleeding, and epistaxis. Female carriers may have menorrhagia. Anemia ranges from minimal (mild dyserythropoiesis) to severe (hydrops fetalis). Severe hemorrhage and/or erythrocyte transfusion dependence may be present lifelong. In a milder phenotype, anemia and the risk for bleeding decrease spontaneously with age.

\section{Diagnosis}

Diagnostic laboratory findings usually include macrothrombocytopenia and normochromic anemia. In contrast to $\delta$-SPD, laboratory analyses revealed impaired primary platelet aggregation in addition to the absence of secondary aggregation. Because of the lack of specificity in aggregation studies, the diagnosis also requires measurement of $\alpha$ - and $\delta$-granule contents and/or electron microscopy to confirm the absence of platelet $\alpha$-granules and the dysplastic features in platelets and MKs [67]. Family history is important as according with Xlinked inheritance.

\section{Wiskott-Aldrich Syndrome}

\section{Introduction}

WAS is a rare X-linked recessive disease characterized by eczema, thrombocytopenia, increased risk of developing autoimmune disease and malignancies, and bloody diarrhea [68]. The clinical picture results from defective platelet and lymphocyte function. The immune deficiency is caused by decreased antibody production, although $\mathrm{T}$ cells are also affected. Isolated X-linked thrombocytopenia (XLT) with small platelets but without immunodeficiency is a clinically mild allelic variant. The three German patients originally described by Wiskott in 1937 died early in life from intestinal bleeding and sepsis [69]. In 1994, WAS was linked to mutations in a gene on the short arm of the $\mathrm{X}$ chromosome, encoding Wiskott-Aldrich syndrome protein (WASP). A frameshift mutation in the WAS gene was found in family members of the originally described patients [70]. The symptomatic individuals were all male, consistent with an X-linked recessive inheritance.

\section{Pathophysiology}

WAS could be considered as a pathology of the cytoskeleton. The $W A S$ gene, encoding for the protein WASP, is mainly expressed in hematopoietic cells and displays a key regulator of actin polymerization. WASP seems to be involved in signal transduction pathways in which tyrosine phosphorylation and adapter protein function have been suggested. Deficiency of WASP induces premature proplatelet formation in the bone marrow where a lack of actin-rich podosomes abrogates MK migration [71]. Both classical and mild forms of WAS result from loss-of-function mutations of WAS, of which hundreds have been described. WAS mutations that confer constitutive WASP activation with increased actin polymerizing activity give rise to an $\mathrm{X}$-linked form of neutropenia with an intrinsic disruption of myelopoiesis through defective mitosis and cytokinesis [72].

\section{Clinical Manifestations}

Patients with WAS present with microthrombocytopenia, moderate to severe eczema, and recurrent infections. Autoimmune disorders are also found in WAS patients. WAS platelets, which are small and do not function properly, are removed by the spleen leading to low platelet counts. Splenomegaly is not an uncommon finding. Platelets may increase in size following splenectomy $[73,74]$.

\section{Diagnosis}

The diagnosis is made on the basis of clinical parameters, blood smear, and low immunoglobulin levels. Typically, serum immunoglobulin ( $\mathrm{Ig}$ ) M level is reduced while $\mathrm{IgG}$ and IgA levels are normal or occasionally elevated. IgE levels may be elevated [75]. WAS platelets aggregate poorly and have a low granule number. T lymphocytes also show impaired function. Decreased levels of WASP and/or confirmation of a causative mutation provide the most definitive diagnosis.

\section{Disclosure}

The authors declared no conflict of interest. 


\section{References}

1 Simon D, Kunicki T, Nugent D: Platelet function defects. Haemophilia 2008;14:1240-1249.

$\checkmark 2$ Nurden P, Nurden AT: Congenital disorders associated with platelet dysfunctions. Thromb Haemost 2008;99:253-263.

3 Raccuglia G: Gray platelet syndrome. A variety of qualitative platelet disorder. Am J Med 1971;51: 818-828.

4 White JG: Ultrastructural studies of the gray platelet syndrome. Am J Pathol 1979;95:445-462.

$\checkmark 5$ Mori K, Suzuki S, Sugai K: Electron microscopic and functional studies on platelets in gray platelet syndrome. Tohoku J Exp Med 1984;143:261-287.

6 Nurden P, Jandrot-Perrus M, Combrie R, Winckler J, Arocas V, Lecut C, Pasquet JM, Kunicki TJ, Nurden AT: Severe deficiency of glycoprotein VI in a patient with gray platelet syndrome. Blood 2004; 104:107-114.

7 Nurden AT, Nurden P: The gray platelet syndrome: clinical spectrum of the disease. Blood Rev 2007;21:21-36.

-8 Jantunen E, Hanninen A, Naukkarinen A, Vornanen M, Lahtinen R: Gray platelet syndrome with splenomegaly and signs of extramedullary hematopoiesis: a case report with review of the literature. Am J Hematol 1994;46:218-224.

-9 Drouin A, Favier R, Masse JM, Debili N, Schmitt A, Elbim C, Guichard J, Adam M, Gougerot-Pocidalo MA, Cramer EM: Newly recognized cellular abnormalities in the gray platelet syndrome. Blood 2001;98:1382-1391.

-10 Nurden AT, Nurden P, Bermejo E, Combrie R, McVicar DW, Washington AV: Phenotypic heterogeneity in the Gray platelet syndrome extends to the expression of TREM family member, TLT-1. Thromb Haemost 2008;100:45-51.

-11 Tracy PB, Giles AR, Mann KG, Eide LL, Hoogendoorn H, Rivard GE: Factor V (Quebec): a bleeding diathesis associated with a qualitative platelet factor V deficiency. J Clin Invest 1984;74:1221-1228.

12 Janeway CM, Rivard GE, Tracy PB, Mann KG: Factor V Quebec revisited. Blood 1996;87:35713578.

13 Hayward CP, Cramer EM, Kane WH, Zheng S, Bouchard M, Masse JM, Rivard GE: Studies of a second family with the Quebec platelet disorder: evidence that the degradation of the alpha-granule membrane and its soluble contents are not secondary to a defect in targeting proteins to alpha-granules. Blood 1997;89:1243-1253.

-14 Hayward CP, Rivard GE, Kane WH, Drouin J, Zheng S, Moore JC, Kelton JG: An autosomal dominant, qualitative platelet disorder associated with multimerin deficiency, abnormalities in platelet factor V, thrombospondin, von Willebrand factor, and fibrinogen and an epinephrine aggregation defect. Blood 1996;87:4967-4978.

15 Kahr WH, Zheng S, Sheth PM, Pai M, Cowie A, Bouchard M, Podor TJ, Rivard GE, Hayward CP: Platelets from patients with the Quebec platelet disorder contain and secrete abnormal amounts of urokinase-type plasminogen activator. Blood 2001; 98:257-265.

16 Diamandis M, Paterson AD, Rommens JM, Veljkovic DK, Blavignac J, Bulman DE, Waye JS, Derome F, Rivard GE, Hayward CP: Quebec platelet disorder is linked to the urokinase plasminogen activator gene (PLAU) and increases expression of the linked allele in megakaryocytes. Blood 2009;113:1543-1546.
17 Paterson AD, Rommens JM, Bharaj B, Blavignac J, Wong I, Diamandis M, Waye JS, Rivard GE, Hayward CP: Persons with Quebec platelet disorder have a tandem duplication of PLAU, the urokinase plasminogen activator gene. Blood 2010;115: 1264-1266.

18 McKay H, Derome F, Haq MA, Whittaker S, Arnold E, Adam F, Heddle NM, Rivard GE, Hayward CP: Bleeding risks associated with inheritance of the Quebec platelet disorder. Blood 2004; 104:159-165.

19 Nezelof C, Dupart MC, Jaubert F, Eliachar E: A lethal familial syndrome associating arthrogryposis multiplex congenita, renal dysfunction, and a cholestatic and pigmentary liver disease. J Pediatr 1979; 94:258-260.

20 Coleman RA, Van Hove JL, Morris CR, Rhoads JM, Summar ML: Cerebral defects and nephrogenic diabetes insipidus with the ARC syndrome: additional findings or a new syndrome (ARCC-NDI)? Am J Med Genet 1997;72:335-338.

21 Gissen P, Johnson CA, Morgan NV, Stapelbroek JM, Forshew T, Cooper WN, McKiernan PJ, Klomp LW, Morris AA, Wraith JE, McClean P, Lynch SA, Thompson RJ, Lo B, Quarrell OW, Di RM, Trembath RC, Mandel H, Wali S, Karet FE, Knisely AS, Houwen RH, Kelly DA, Maher ER: Mutations in VPS33B, encoding a regulator of SNARE-dependent membrane fusion, cause arthrogryposis-renal dysfunction-cholestasis (ARC) syndrome. Nat Genet 2004;36:400-404.

22 Lo B, Li L, Gissen P, Christensen H, McKiernan PJ, Ye C, Abdelhaleem M, Hayes JA, Williams MD, Chitayat D, Kahr WH: Requirement of VPS33B, a member of the Sec1/Munc18 protein family, in megakaryocyte and platelet alpha-granule biogenesis. Blood 2005;106:4159-4166.

23 Gissen P, Tee L, Johnson CA, Genin E, Caliebe A, Chitayat D, Clericuzio C, Denecke J, Di RM, Fischler B, FitzPatrick D, Garcia-Cazorla A, Guyot D, Jacquemont S, Koletzko S, Leheup B, Mandel H, Sanseverino MT, Houwen RH, McKiernan PJ, Kelly DA, Maher ER: Clinical and molecular genetic features of ARC syndrome. Hum Genet 2006; 120:396-409.

24 Cullinane AR, Straatman-Iwanowska A, Zaucker A, Wakabayashi Y, Bruce CK, Luo G, Rahman F, Gurakan F, Utine E, Ozkan TB, Denecke J, Vukovic J, Di RM, Mandel H, Cangul H, Matthews RP, Thomas SG, Rappoport JZ, Arias IM, Wolburg H, Knisely AS, Kelly DA, Muller F, Maher ER, Gissen P: Mutations in VIPAR cause an arthrogryposis, renal dysfunction and cholestasis syndrome phenotype with defects in epithelial polarization. Nat Genet 2010;42:303-312.

25 Jang JY, Kim KM, Kim GH, Yu E, Lee JJ, Park YS, Yoo HW: Clinical characteristics and VPS33B mutations in patients with ARC syndrome. J Pediatr Gastroenterol Nutr 2009;48:348-354.

26 Eastham KM, McKiernan PJ, Milford DV, Ramani P, Wyllie J, van't Hoff W, Lynch SA, Morris AA: ARC syndrome: an expanding range of phenotypes. Arch Dis Child 2001;85:415-420.

27 Jedlitschky G, Cattaneo M, Lubenow LE, Rosskopf D, Lecchi A, Artoni A, Motta G, Niessen J, Kroemer HK, Greinacher A: Role of MRP4 (ABCC4) in platelet adenine nucleotide-storage: evidence from patients with delta-storage pool deficiencies. Am J Pathol 2010;176:1097-1103.

28 Hermansky F, Pudlak P: Albinism associated with hemorrhagic diathesis and unusual pigmented reticular cells in the bone marrow: report of two cases with histochemical studies. Blood 1959;14:162-169.
Cutler DF: Introduction: lysosome-related organelles. Semin Cell Dev Biol 2002;13:261-262.

30 Dell'Angelica EC, Mullins C, Caplan S, Bonifacino JS: Lysosome-related organelles. FASEB J 2000;14: 1265-1278.

-31 Summers CG, Knobloch WH, Witkop CJ Jr, King RA: Hermansky-Pudlak syndrome. Ophthalmic findings. Ophthalmology 1988;95:545-554.

32 Schallreuter KU, Frenk E, Wolfe LS, Witkop CJ, Wood JM: Hermansky-Pudlak syndrome in a Swiss population. Dermatology 1993;187:248-256.

33 Witkop CJ, Nunez BM, Rao GH, Gaudier F, Summers CG, Shanahan F, Harmon KR, Townsend D, Sedano HO, King RA, et al: Albinism and Hermansky-Pudlak syndrome in Puerto Rico. Bol Asoc Med P R 1990;82:333-339.

34 Li W, Rusiniak ME, Chintala S, Gautam R, Novak EK, Swank RT: Murine Hermansky-Pudlak syndrome genes: regulators of lysosome-related organelles. Bioessays 2004;26:616-628.

35 Korswagen LA, Huizing M, Simsek S, Janssen JJ, Zweegman S: A novel mutation in a Turkish patient with Hermansky-Pudlak syndrome type 5 . Eur J Haematol 2008;80:356-360.

36 Enders A, Zieger B, Schwarz K, Yoshimi A, Speckmann C, Knoepfle EM, Kontny U, Muller C, Nurden A, Rohr J, Henschen M, Pannicke U, Niemeyer C, Nurden P, Ehl S: Lethal hemophagocytic lymphohistiocytosis in Hermansky-Pudlak syndrome type II. Blood 2006;108:81-87.

37 Huizing M, Pederson B, Hess RA, Griffin A, HelipWooley A, Westbroek W, Dorward H, O'Brien KJ, Golas G, Tsilou E, White JG, Gahl WA: Clinical and cellular characterisation of Hermansky-Pudlak syndrome type 6. J Med Genet 2009;46:803-810.

38 Li W, Zhang Q, Oiso N, Novak EK, Gautam R, O'Brien EP, Tinsley CL, Blake DJ, Spritz RA, Copeland NG, Jenkins NA, Amato D, Roe BA, Starcevic M, Dell'Angelica EC, Elliott RW, Mishra V, Kingsmore SF, Paylor RE, Swank RT: Hermansky-Pudlak syndrome type 7 (HPS-7) results from mutant dysbindin, a member of the biogenesis of lysosome-related organelles complex 1 (BLOC-1). Nat Genet 2003;35:84-89.

39 Fallgatter AJ, Ehlis AC, Herrmann MJ, Hohoff C, Reif A, Freitag CM, Deckert J: DTNBP1 (Dysbindin) gene variants modulate prefrontal brain function in schizophrenic patients - support for the glutamate hypothesis of schizophrenias. Genes Brain Behav 2010;9:489-497.

40 Strohmaier J, Frank J, Wendland JR, Schumacher J, Jamra RA, Treutlein J, Nieratschker V, Breuer R, Mattheisen M, Herms S, Muhleisen TW, Maier W, Nothen MM, Cichon S, Rietschel M, Schulze TG: A reappraisal of the association between Dysbindin (DTNBP1) and schizophrenia in a large combined case-control and family-based sample of German ancestry. Schizophr Res 2010;118:98-105.

41 Morgan NV, Pasha S, Johnson CA, Ainsworth JR, Eady RA, Dawood B, McKeown C, Trembath RC, Wilde J, Watson SP, Maher ER: A germline mutation in BLOC1S3/reduced pigmentation causes a novel variant of Hermansky-Pudlak syndrome (HPS8). Am J Hum Genet 2006;78:160-166.

42 Sato A: Chediak and Higashi's disease: probable identity of a new leucocytal anomaly (Chediak) and congenital gigantism of peroxidase granules (Higashi). Tohoku J Exp Med 1955;61:201-210.

43 Donohue WL, Bain HW: Chediak-Higashi syndrome; a lethal familial disease with anomalous inclusions in the leukocytes and constitutional stigmata: report of a case with necropsy. Pediatrics 1957;20:416-430. 
44 Barbosa MD, Nguyen QA, Tchernev VT, Ashley JA, Detter JC, Blaydes SM, Brandt SJ, Chotai D, Hodgman C, Solari RC, Lovett M, Kingsmore SF: Identification of the homologous beige and Chediak-Higashi syndrome genes. Nature 1996;382: 262-265.

45 Nagle DL, Karim MA, Woolf EA, Holmgren L, Bork P, Misumi DJ, McGrail SH, Dussault BJ Jr, Perou CM, Boissy RE, Duyk GM, Spritz RA, Moore KJ: Identification and mutation analysis of the complete gene for Chediak-Higashi syndrome. Nat Genet 1996;14:307-311.

46 Karim MA, Suzuki K, Fukai K, Oh J, Nagle DL, Moore KJ, Barbosa E, Falik-Borenstein T, Filipovich A, Ishida Y, Kivrikko S, Klein C, Kreuz F, Levin A, Miyajima H, Regueiro J, Russo C, Uyama E, Vierimaa O, Spritz RA: Apparent genotype-phenotype correlation in childhood, adolescent, and adult Chediak-Higashi syndrome. Am J Med Genet 2002;108:16-22.

47 Certain S, Barrat F, Pastural E, Le DF, GoyoRivas J, Jabado N, Benkerrou M, Seger R, Vilmer E, Beullier G, Schwarz K, Fischer A, de Saint BG: Protein truncation test of LYST reveals heterogenous mutations in patients with Chediak-Higashi syndrome. Blood 2000;95:979-983.

48 Eapen M, DeLaat CA, Baker KS, Cairo MS, Cowan MJ, Kurtzberg J, Steward CG, Veys PA, Filipovich AH: Hematopoietic cell transplantation for Chediak-Higashi syndrome. Bone Marrow Transplant 2007;39:411-415.

49 Griscelli C, Durandy A, Guy-Grand D, Daguillard F, Herzog C, Prunieras M: A syndrome associating partial albinism and immunodeficiency. Am J Med 1978;65:691-702.

50 Griscelli C, Prunieras M: Pigment dilution and immunodeficiency: a new syndrome. Int J Dermatol 1978;17:788-791.

-51 Pastural E, Barrat FJ, Dufourcq-Lagelouse R, Certain S, Sanal O, Jabado N, Seger R, Griscelli C, Fischer A, de Saint BG: Griscelli disease maps to chromosome $15 \mathrm{q} 21$ and is associated with mutations in the myosin-Va gene. Nat Genet 1997;16: 289-292.

52 Menasche G, Ho CH, Sanal O, Feldmann J, Tezcan I, Ersoy F, Houdusse A, Fischer A, de Saint BG: Griscelli syndrome restricted to hypopigmentation results from a melanophilin defect (GS3) or a MYO5A F-exon deletion (GS1). J Clin Invest 2003; 112:450-456.
53 Menasche G, Pastural E, Feldmann J, Certain S, Ersoy F, Dupuis S, Wulffraat N, Bianchi D, Fischer A, Le DF, de Saint BG: Mutations in RAB27A cause Griscelli syndrome associated with haemophagocytic syndrome. Nat Genet 2000;25:173-176.

54 Barral DC, Seabra MC: The melanosome as a model to study organelle motility in mammals. Pigment Cell Res 2004;17:111-118.

-55 Pastural E, Ersoy F, Yalman N, Wulffraat N, Grillo E, Ozkinay F, Tezcan I, Gedikoglu G, Philippe N, Fischer A, de Saint BG: Two genes are responsible for Griscelli syndrome at the same 15q21 locus. Genomics 2000;63:299-306.

56 Ivanovich J, Mallory S, Storer T, Ciske D, Hing A: 12-year-old male with Elejalde syndrome (neuroectodermal melanolysosomal disease). Am J Med Genet 2001;98:313-316

57 Menasche G, Fischer A, de Saint BG: Griscelli syndrome types 1 and 2. Am J Hum Genet 2002;71: 1237-1238.

58 Bahadoran P, Ortonne JP, Ballotti R, de SaintBasile G: Comment on Elejalde syndrome and relationship with Griscelli syndrome. Am J Med Genet A 2003;116A:408-409.

59 Wilson SM, Yip R, Swing DA, O'Sullivan TN, Zhang Y, Novak EK, Swank RT, Russell LB, Copeland NG, Jenkins NA: A mutation in Rab27a causes the vesicle transport defects observed in ashen mice. Proc Natl Acad Sci U S A 2000;97: 7933-7938.

60 Biddle DA, Neto TG, Nguyen AN: Platelet storage pool deficiency of alpha and delta granules. Arch Pathol Lab Med 2001;125:1125-1126.

61 Nichols KE, Crispino JD, Poncz M, White JG, Orkin SH, Maris JM, Weiss MJ: Familial dyserythropoietic anaemia and thrombocytopenia due to an inherited mutation in GATA1. Nat Genet 2000;24: 266-270.

62 Del Vecchio GC, Giordani L, De SA, De MD: Dyserythropoietic anemia and thrombocytopenia due to a novel mutation in GATA-1. Acta Haematol 2005;114:113-116.

63 Phillips JD, Steensma DP, Pulsipher MA, Spangrude GJ, Kushner JP: Congenital erythropoietic porphyria due to a mutation in GATA1: the first transacting mutation causative for a human porphyria. Blood 2007;109:2618-2621.

64 Crispino JD: GATA1 in normal and malignant hematopoiesis. Semin Cell Dev Biol 2005;16:137-147.
65 Freson K, Matthijs G, Thys C, Marien P, Hoylaerts MF, Vermylen J, Van GC: Different substitutions at residue $\mathrm{D} 218$ of the $\mathrm{X}$-linked transcription factor GATA1 lead to altered clinical severity of macrothrombocytopenia and anemia and are associated with variable skewed $\mathrm{X}$ inactivation. Hum $\mathrm{Mol}$ Genet 2002;11:147-152.

66 Mehaffey MG, Newton AL, Gandhi MJ, Crossley M, Drachman JG: X-linked thrombocytopenia caused by a novel mutation of GATA-1. Blood 2001;98:2681-2688.

67 White JG: Inherited abnormalities of the platelet membrane and secretory granules. Hum Pathol 1987;18:123-139.

68 Aldrich RA, Steinberg AG, Campbell DC: Pedigree demonstrating a sex-linked recessive condition characterized by draining ears, eczematoid dermatitis and bloody diarrhea. Pediatrics 1954;13: 133-139.

69 Wiskott A: Familiärer angeborener Morbus Werlhofii? Mschr Kinderheilk 1937;68:212-216.

70 Binder V, Albert MH, Kabus M, Bertone M, Meindl A, Belohradsky BH: The genotype of the original Wiskott phenotype. N Engl J Med 2006;355:1790-1793.

71 Sabri S, Foudi A, Boukour S, Franc B, Charrier S, Jandrot-Perrus M, Farndale RW, Jalil A, Blundell MP, Cramer EM, Louache F, Debili N, Thrasher AJ, Vainchenker W: Deficiency in the WiskottAldrich protein induces premature proplatelet formation and platelet production in the bone marrow compartment. Blood 2006;108:134-140.

72 Ancliff PJ, Blundell MP, Cory GO, Calle Y, Worth A, Kempski H, Burns S, Jones GE, Sinclair J, Kinnon C, Hann IM, Gale RE, Linch DC, Thrasher AJ: Two novel activating mutations in the WiskottAldrich syndrome protein result in congenital neutropenia. Blood 2006;108:2182-2189.

73 Sullivan KE, Mullen CA, Blaese RM, Winkelstein JA: A multiinstitutional survey of the Wiskott-Aldrich syndrome. J Pediatr 1994;125:876-885.

74 Corash L, Shafer B, Blaese RM: Platelet-associated immunoglobulin, platelet size, and the effect of splenectomy in the Wiskott-Aldrich syndrome. Blood 1985;65:1439-1443.

75 Standen GR, Lillicrap DP, Matthews N, Bloom AL: Inherited thrombocytopenia, elevated serum IgA and renal disease: identification as a variant of the Wiskott-Aldrich syndrome. Q J Med 1986;59: 401-408. 